ROZDZIAŁ 1

\title{
Problemy rozwoju miast europejskich okresu postindustrialnego
}

\subsection{Pierwszy światowy kryzys energetyczny, upadek tradycyjnych gałęzi przemysłu. Raport Bruntland - idea zrównoważonego rozwoju}

Przemysł w Europie przez prawie dwa wieki - od początku epoki industrializacji (XVIII w.) do drugiej połowy XX w., a w Polsce od połowy wieku XIX ${ }^{1}$ - stanowił istotną ,siłę napędową" rozwoju miast i był jednym ze znaczących czynników sprawczych urbanizacji. Tworzył bazę gospodarczej egzystencji wielu miast, ale był też jednocześnie przyczyną wzrastających napięć społecznych i lawinowej degradacji środowiska naturalnego.

W drugiej połowie XX w. kryzys tradycyjnych gałęzi przemysłu, o dużej uciążliwości ekologicznej, był początkiem drogi do uświadomienia sobie konieczności ochrony środowiska naturalnego. Stwierdzenia dotyczące tej kwestii pojawiły się już w 1970 r. w wystapieniu Sekretarza Generalnego ONZ U Thanta oraz w deklaracji ONZ Sztokholm 1972.

W 1987 r. Światowa Komisja Środowiska i Rozwoju opublikowała tzw. Raport Bruntland noszący tytuł Nasza Wspólna Przyszłość, w którym sformułowano podstawowe zasady rozwoju zrównoważonego (sustainable development), określające nowe podejście do kwestii gospodarowania odnawialnymi i nieodnawialnymi zasobami środowiska naturalnego. Za cel nadrzędny uznano takie gospodarowanie zasobami, aby nie ograniczać możliwości korzystania z nich przez przyszłe pokolenia w skali lokalnej i globalnej oraz zapewnić społeczeństwom możliwość harmonijnego rozwoju. Znaczenie tego określenia sprecyzowane zostało ostatecznie w deklaracji Agenda 21, przyjętej na Konferencji ONZ Środowisko i Rozwój (nazywanej Szczytem Ziemi) w Rio de Janeiro w $1992 \mathrm{r}$.

\footnotetext{
${ }^{1}$ Urbanizacja na terenach ziem polskich miała niemal do połowy XX w. charakter ziemiański i wiejski, a początki urbanizacji związanej z uprzemysłowieniem na wzór zachodnioeuropejski zapoczątkowane zosały dopiero w drugiej połowie XIX w., w takich miastach, jak Łódź, Zgierz, Żyrardów, Sosnowiec, Dąbrowa Górnicza czy Warszawa. (Raport wprowadzający Ministerstwa Rozwoju Regionalnego opracowany na potrzeby przygotowania Przegladu OECD krajowej polityki miejskiej w Polsce. Rozwój miast w Polsce, Warszawa 2010, s. 8).
} 
Zasada zrównoważonego rozwoju została uznana przez wiele krajów na świecie, w tym kraje Unii Europejskiej, za podstawę planowania dalszego rozwoju cywilizacyjnego, determinująca jakość życia obecnych i przyszłych pokoleń. Niezbędnym elementem rozwoju zrównoważonego stała się także rewitalizacja terenów i obiektów poprzemysłowych oraz zdegradowanych obszarów miejskich. Okazało się, że ich ponowne włączenie w strukturę przestrzenno-funkcjonalną miast oraz w życie społeczne i gospodarcze, dzięki nadaniu im nowej funkcji oraz dostosowanie do współczesnych standardów dotyczących jakości środowiska zamieszkania, w znaczącym stopniu warunkuje rozwiązywanie problemów ekonomicznych, społecznych i środowiskowych, a także stanowi instrument przeciwdziałania zapaści centralnych stref miejskich. Ponadto, w myśl zasady zrównoważonego rozwoju, przestrzeń stanowi dobro nieodnawialne i jako takie musi być zagospodarowywana w sposób racjonalny i oszczędny. Działania związane z rewitalizacją zarówno zdegradowanych obszarów miejskich, jak i obszarów poprzemysłowych umożliwiają takie właśnie gospodarowanie przestrzenią - poprzez powtórne wykorzystywanie obszarów już wcześniej zagospodarowanych (brownfields), a nie anektowanie coraz to nowych, dotychczas niezurbanizowanych, obszarów (greenfields).

\subsection{Cykl rozwoju miejskiego. \\ Rewitalizacja jako narzędzie reurbanizacji}

Według koncepcji cyklu życia miejskiego Leo von Klaassena ${ }^{2}$, miasta rozwijają się w następujących fazach: urbanizacji, suburbanizacji i dezurbanizacji.

Faza urbanizacji polega na koncentracji ludności w miastach $\mathrm{w}$ wyniku industrializacji. Następuje w niej wzrost liczby ludności w centrach miast i otaczających je dzielnicach oraz spadek lub stagnacja na obrzeżach miasta. W fazie suburbanizacji dochodzi do znaczącego rozrostu przestrzennego miasta - zmniejszeniu ulega liczba ludności w centrum miasta, w wyniku jej odpływu do strefy podmiejskiej. Zbyt niska intensywność wykorzystania centrum i terenów śródmiejskich związana jest z coraz szerszym „rozlewaniem się" terenów miast i anektowaniem nowych obszarów dotychczas niezurbanizowanych (tzw. urban sprawl).

W stadium dezurbanizacji następuje dalszy spadek liczby mieszkańców dzielnic centralnych miasta i odpływ ludności na obszary zewnętrzne, pozamiejskie - co powoduje zmniejszenie ogólnej liczby mieszkańców zarówno strefy centralnej, jak i całego miasta. Zjawisko to związane jest z przenosze-

\footnotetext{
${ }^{2}$ L. Klaassen, Area Economic and Social Redevelopment, Paris 1965.
} 
niem się ludności do nowych zespołów zabudowy mieszkaniowej jednoi wielorodzinnej na obrzeżach miast lub nawet poza jego granicami, z powodu degradacji technicznej i społecznej obszarów śródmiejskich. W tej fazie centrum miasta może tracić istotne funkcje charakterystyczne dla śródmiejskich dzielnic, co związane jest z postępującą degradacją przestrzenną i społeczną tych rejonów ${ }^{3}$ (ryc. 1).

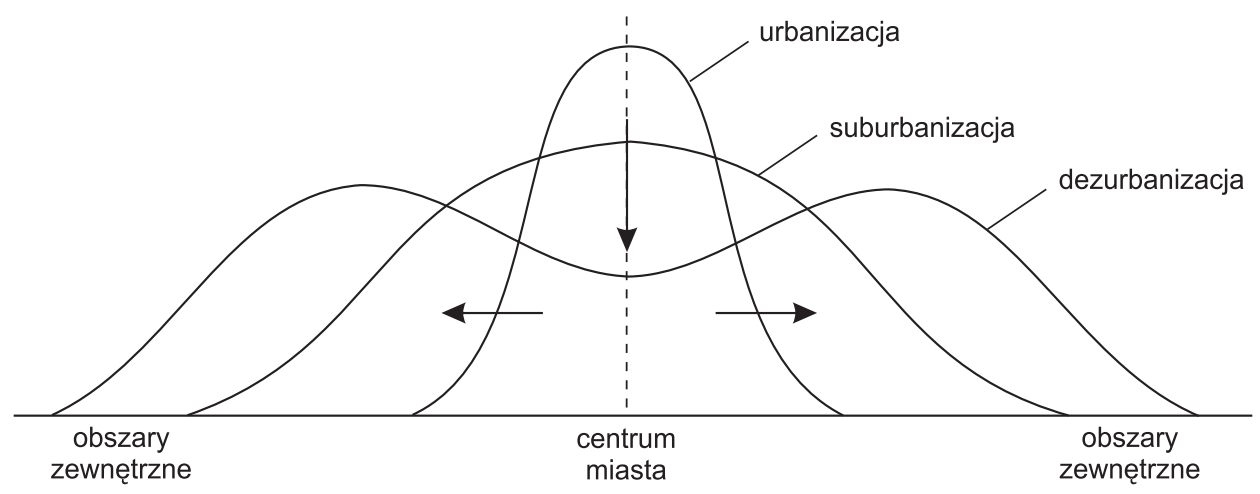

Ryc. 1. Rozmieszczenie ludności na obszarze miasta w poszczególnych stadiach urbanizacji - tzw. model Klaassena

Jako kolejną fazę rozwoju miast niektórzy badacze wymieniają fazę reurbanizacji, określając $w$ ten sposób działania zmierzające do ponownego ożywienia i odnowy centralnych obszarów miasta. Jako jedno z podstawowych narzędzi $\mathrm{w}$ procesie reurbanizacji wymieniana jest rewitalizacja. Realizacja procesu rewitalizacji ma prowadzić do likwidacji przyczyn upadku dzielnic centralnych, poprzez podniesienie działania na rzecz poprawy jakości środowiska miejskiego, w tym jego walorów ekologicznych i technicznych, a także rozwiązywanie problemów społecznych i gospodarczych. Istotną rolę w procesie reurbanizacji może także odgrywać rewitalizacja terenów i obiektów poprzemysłowych, w wyniku adaptacji dla nowych funkcji zasobów poprzemysłowych, często zlokalizowanych $\mathrm{w}$ strefach śródmiejskich i stanowiących atrakcyjną sposobność pozyskania na cele nowych inwestycji obszarów i obiektów zlokalizowanych w bezpośrednim sąsiedztwie centrum miasta.

Wydaje się, że w chwili obecnej ścieżka rewitalizacji - pomimo wielu trudności, jakie napotyka wdrażanie tego procesu - jest istotną drogą prowadzącą do zachowania integralności miast i ciągłości tradycji miejskiej w rozwoju cywilizacji europejskiej.

${ }^{3} \mathrm{O}$ dezurbanizacji pisze m.in. J. J. Parysek, Miasta polskie na przełomie XX i XXI wieku. Rozwój i przeksztatcenia strukturalne, Poznań 2005. 


\subsection{Przyczyny degradacji terenów miejskich}

W przypadku miast polskich, można mówić o równoczesnym zaistnieniu trzech zasadniczych negatywnych czynników, mających wpływ na stan obecny i możliwości rozwoju:

- dekapitalizacja i degradacja substancji budowlanej (tzw. „luka remontowa”),

- skutki związane z procesami globalizacji,

- społeczno-gospodarcze skutki transformacji ${ }^{4}$.

Rozwój funkcji przemysłowej był bodźcem do znacznego wzrostu wielu miast polskich poczynając od połowy XIX w. W tym okresie powstawały obszary zwartej zabudowy śródmiejskiej o charakterze mieszkaniowym, mające zabezpieczyć minimum standardu życiowego napływającej masowo do miast ludności, poszukującej zatrudnienia $\mathrm{w}$ przemyśle. Tereny te charakteryzowały się niekorzystnymi warunkami życia, ze względu na przeludnienie, niską jakość techniczną zabudowy oraz brak podstawowej infrastruktury higieniczno-sanitarnej.

Sytuacja $\mathrm{w}$ tych obszarach miast uległa jeszcze pogorszeniu po II wojnie światowej. Począwszy od lat pięćdziesiątych, forsowna industrializacja kraju w okresie gospodarki socjalistycznej spowodowała masowy napływ ludności do miast i przeludnienie stref centralnych i staromiejskich, stanowiących wówczas obszar koncentracji zasobów mieszkaniowych. W wyniku przemieszczeń ludności, spowodowanych przede wszystkim przez uprzemysłowienie, w roku 1966 w miastach w Polsce zamieszkiwała ponad połowa ludności całego kraju ${ }^{5}$. Konieczne było szybkie zapewnienie jak największej liczby nowych mieszkań dla lawinowo wzrastającej liczby ludności. Lata siedemdziesiąte to okres intensywnej urbanizacji w Polsce, związanej z tzw. drugą fazą uprzemysłowienia, której cechą charakterystyczną była rewolucja naukowo-techniczna i wzrost wykwalifikowanej siły roboczej w procesach produkcji. Procesy urbanizacyjne $\mathrm{w}$ tym okresie wiązały się $\mathrm{z}$ polityką państwa, zmierzającą do podniesienia standardów życia i zwiększenia stopnia realizacji potrzeb konsumpcyjnych społeczeństwa, w tym mieszkaniowych ${ }^{6}$.

Poza strefą śródmiejską, anektując zewnętrzne tereny dotychczas niezurbanizowane, zaczęły powstawać wielorodzinne osiedla mieszkaniowe, tzw. blokowiska, oferujące nowe mieszkania o przyzwoitym standardzie w zakresie wyposażenia $\mathrm{w}$ infrastrukturę techniczną, zieleń i podstawowe usługi. Nowe dzielnice mieszkaniowe, otaczające pierścieniem XIX-wieczne obszary miejskie, zapełniały

\footnotetext{
${ }^{4}$ Urząd Mieszkalnictwa i Rozwoju Miast, Podręcznik rewitalizacji. Zasady, procedury i metody działania wspótczesnych procesów rewitalizacji, Warszawa 2003, s. 22.

${ }^{5}$ Raport wprowadzajacy Ministerstwa Rozwoju Regionalnego opracowany na potrzeby przygotowania Przegladu OECD krajowej polityki miejskiej $w$ Polsce. Rozwój miast w Polsce, Warszawa 2010, s. 10.

${ }^{6}$ Tamże, s. 11.
} 
się mieszkańcami z rejonów śródmiejskich oraz przyciagaały nowych mieszkańców $\mathrm{z}$ terenów pozamiejskich. Jak pisze Z. Zioło, „W warunkach krajowych, w fazie industrialnej przemysł traktowany był jako wiodący czynnik intensyfikujący wzrost i przemiany struktur przestrzennych"7.

Liczba mieszkańców w rejonach centralnych miast zaczęła maleć, ale niestety nie spowodowało to podniesienia jakości zabudowy tych stref miasta. Zjawisko to - występująca przez kilkadziesiąt lat $\mathrm{w}$ wielu miastach polskich $\mathrm{w}$ rejonach zabudowy historycznej tzw. luka remontowa - miało podłoże polityczne i społeczne. W okresie powojennym władze socjalistyczne celowo nie podejmowały działań remontowych $\mathrm{w}$ dzielnicach śródmiejskich, stanowiących materialny dowód kapitalistycznej przeszłości - co miało doprowadzić (i często niestety doprowadzało) do stopniowej śmierci technicznej tych części miasta.

W starych zasobach mieszkaniowych zlokalizowanych w centralnych dzielnicach miast często pozostawała ludność najuboższa, mało aktywna życiowo, ludzie starsi i o niższym statusie społecznym. Ludzie młodsi i lepiej wykształceni oraz zamożniejsi w miarę możliwości opuszczali niskiej jakości mieszkania w zabudowie śródmiejskiej i staromiejskiej, przenosząc się do nowo budowanych na obrzeżach miast osiedli wielorodzinnych lub do dzielnic zabudowy jednorodzinnej. W obszarach śródmiejskich zaczęły często kumulować się negatywne zjawiska patologii społecznych i wykluczenia społecznego oraz upadku gospodarczego. Ponadto, jako dziedzictwo poprzednich okresów rozwoju miasta, pozostały liczne mankamenty środowiska miejskiego: niewydolna, nieprzystosowana do współczesnych realiów komunikacyjnych sieć uliczna, brak zieleni i terenów rekreacyjnych, nadal utrzymujące się braki w wyposażeniu w media, zanieczyszczenie środowiska, niewłaściwe warunki mieszkaniowe pod względem doświetlenia i przewietrzania, degradacja techniczna zasobów budowlanych oraz dewastacja zagospodarowania otaczających zabudowę terenów. Pozostałością po okresie ogromnego zagęszczenia ludności w centrach miast była także niekorzystna struktura mieszkań - często wydzielanych jako jednoizbowe $\mathrm{z}$ dawnych dużych apartamentów, ze wspólnymi kuchniami i węzłami sanitarnymi dla wszystkich mieszkań.

W warunkach polskich możemy mówić o równoległym wystapieniu skutków związanych z procesem globalizacji i społeczno-gospodarczych skutków transformacji ustrojowej - oba te zjawiska zaczęły oddziaływać na miasta polskie po roku 1989. Kumulacja problemów postawiła miasta polskie w szczególnie trudnej sytuacji, także z tego względu, że w Polsce nie było i nadal nie ma wsparcia dla działań rewitalizacyjnych na poziomie krajowym, a zewnętrzne fundusze publiczne (środki finansowe UE) stały się dostępne dla naszych samorządów dopiero w roku 2004.

${ }^{7}$ Z. Zioło, Wplyw przemystu na rozwój społeczno-ekonomiczny regionu rzeszowskiego, Warszawa 1980. 